\title{
DIVULGAÇÃO CIENTÍFICA NA LUTA CONTRA NOTÍCIAS FALSAS EM TEMPOS DE COVID-19
}

\author{
Raiane Araujo Brandão \\ Discente do curso Integrado técnico em informática. Instituto Federal de Educação, Ciência e Tecnologia da \\ Bahia (IFBA) Campus Seabra. \\ https://orcid.org/0000-0002-6042-4679 \\ Rafaelle da Silva Souza \\ Doutora em Ensino, Filosofia e História das Ciências. Instituto Federal de Educação, Ciência e Tecnologia \\ da Bahia (IFBA) Campus Seabra. \\ https://orcid.org/0000-0001-6713-2292
}

Data de submissão: 25/09/2020

Data de aprovação: 24/10/2020

\section{RESUMO}

Este artigo tem o propósito de apresentar o projeto Checker News, bem como analisar a relevância da divulgação científica como mecanismo para minorar as consequências deletérias da veiculação de notícias falsas sobre a Covid-19, através do compartilhamento de conteúdo com linguagem acessível e científica no perfil do Instagram @fisica_contextualizada. A escolha desse perfil deu-se por já constar um número inicial de seguidores $(n=435)$, o que facilitaria o conhecimento inicial das ações do projeto. A pesquisa de caráter descritivo avaliou o perfil do Instagram cadastrado na área de Educação com categorias definidas na rede social. Apresentamos e discutimos as ações do projeto que ocorreu no período de junho a agosto de 2020, que se refere à prestação de serviços de informação. Para tanto, dialogamos com a literatura sobre a divulgação científica, bem como sobre os processos, recursos e técnicas para a veiculação de informações científicas, tecnológicas ou associadas a inovações ao público leigo observando como potencializa os processos de ensino e aprendizagem. Em seguida, trazemos os resultados iniciais do projeto na perspectiva de compreender o impacto da divulgação científica em perfil no Instagram para o combate às Fake News em época da pandemia do coronavírus. Finalmente, argumentamos que o desenvolvimento de projetos dessa natureza possibilita um trabalho de educação científica, que tem por consequência a compreensão da importância da ciência para a sociedade.

Palavras-chave: Covid-19. Fake News. Divulgação Científica.

\section{SCIENTIFIC DISSEMINATION IN THE FIGHT AGAINST FAKE NEWS IN THE COVID-19 TIMES}

\section{ABSTRACT}

This article aims to present the Checker News project, as well as analyze the relevance of scientific dissemination as a mechanism to mitigate the deleterious consequences of the delivery of fake news about Covid-19 through sharing content with accessible and scientific language on Instagram profile @fisica_contextualizada. The choice of this profile was already an initial number of followers ( $n=435)$ which would facilitate the initial knowledge of the actions of the project. The descriptive research assessed the profile of Instagram 
registered in the Education area with categories defined in the social media. We discuss the actions of the project that took place in the period of June and August 2020, which refers to the provision of information services. To this end, we dialogue with the literature on scientific dissemination, as well as on the processes, resources and techniques for the transmission of scientific information, technological or associated with innovations to the lay public observing how it enhances the teaching and learning processes. Next, we bring the initial results of the project in the perspective of understanding the impact of scientific dissemination on Instagram profile to combat Fake News at the time of the coronavirus pandemic. Finally, we argue that the development of projects of this nature makes possible a work of scientific education, which has as a consequence the understanding of the importance of science for society.

Keywords: Covid-19. Fake News. Scientific Dissemination.

\section{DIVULGACIÓN CIENTÍFICA EN LA LUCHA CONTRA NOTICIAS FALSAS EN TIEMPOS DE COVID-19}

\section{RESUMEN}

Este artículo tiene el propósito de presentar el proyecto Checker News, así como analizar la relevancia de la divulgación científica como mecanismo para mitigar las consecuencias deletéreas de difundir noticias falsas sobre Covid-19, al compartir contenido con lenguaje accesible y científico en el perfil de Instagram @fisica_contextualizada. Se eligió este perfil porque ya contaba con un número inicial de seguidores ( $n=435)$, lo que facilitaría el conocimiento inicial de las acciones del proyecto. La investigación descriptiva evaluó el perfil de Instagram registrado en el área de Educación con categorías definidas en dicha red social. Presentamos y discutimos las acciones del proyecto que se desarrolló de junio a agosto de 2020, que se refiere a la prestación de servicios de información. Para ello, dialogamos con la literatura sobre divulgación científica, así como sobre los procesos, recursos y técnicas para la transmisión de informaciones científicas, tecnológicas o relacionadas a las innovaciones al público no especializado, observando cómo se potencian los procesos de enseñanza y aprendizaje. Luego, traemos los resultados iniciales del proyecto en la perspectiva de entender el impacto de la divulgación científica en perfil en Instagram para combatir las Fake News en tiempos de la pandemia de coronavirus. Finalmente, sostenemos que el desarrollo de proyectos de esta naturaleza posibilita el trabajo de educación científica, lo que tiene como consecuencia comprender la importancia de la ciencia para la sociedad.

Palabras clave: COVID-19. Fake News. Divulgación científica.

\section{INTRODUÇÃO}

Há mais de sete meses, a sociedade brasileira tem enfrentando, em proporções alarmantes, a pandemia de Covid-19. Ao mesmo tempo, a população é bombardeada, a todo instante, com muita informação. Entretanto, muitas informações são confusas ou falsas. Na contramão de combate à Covid-19, a sociedade precisa enfrentar a disseminação de Fake News (Notícias Falsas) que se alastraram na internet.

As notícias falsas, geralmente exageradas ou imprecisas, costumeiramente são chamativas e sensacionalistas, publicadas na internet como se fossem informações reais e com embasamento científico, mas que não ocorreu um processo de apuração do fato (BRAGA, 2018). Nas redes sociais, essas informações são compartilhadas rapidamente e 
se passando por verdades, confundem os leitores e tem grande potencial de aumentar ainda mais um determinado problema (ALLCOTT; GENTZKOW, 2017).

No caso da Covid-19, no início da doença, pouco se conhecia e rapidamente se instaurou um clima de medo e enorme insegurança por parte da população. Um mar de desinformação se propagou pelas redes sociais. Como é sabido, "a desinformação deixa as pessoas mais vulneráveis à doença e espalha o medo e a estigmatização, além de promover caos e histeria" (GAROFALO, 2020). Em consequência, enquanto a comunidade científica de todo mundo respondeu de forma rápida e com muito empenho a esta crise, percebeu-se a necessidade da população fazer a sua parte. Para isso, estar bem informado e agir conscientemente tornou-se essencial para a autoproteção, bem como da sociedade.

É verdade que as grandes corporações por trás dessas redes estão lançando mão de estratégias para combater as notícias falsas. O Facebook, por exemplo, tem contrato com a agência especializada em fact-checking, a LUPA, pioneira no Brasil. Essa agência checa diariamente o grau de veracidade de conteúdos publicados na plataforma, o que acaba diminuindo o fluxo dessas informações (LUPA, 2018). Outra agência brasileira de checagem é a BOATOS que verifica e compila notícias que circulam online e as desmentem em seu site boatos.org, atualizando-o diariamente (MATSUKI, 2013). No entanto, 0 combate à desinformação e à contrainformação ainda é bastante incipiente.

Nesse sentido, a segunda autora deste artigo propôs e coordenou o projeto de extensão 'Checker News: combatendo a perpetuação das notícias falsas na internet sobre a Covid-19', de prestação de serviços à comunidade em caráter emergencial e excepcional, vinculado ao Instituto Federal da Bahia (IFBA), campus Seabra. Esse projeto teve duração de três meses, de junho a agosto de 2020 , e contou com a colaboração da primeira autora para produção de conteúdo. O objetivo geral é divulgar informações confiáveis e em linguagem acessível sobre a doença e sobre como lidar com os novos desafios no cenário adverso da pandemia, deliberando pelo combate às notícias falsas que foram divulgadas e compartilhadas nas redes sociais. Como objetivo especifico, visa-se contribuir com a comunidade de Seabra-BA e região, promovendo a compreensão da importância da ciência e do acesso à informação.

A comunidade de Seabra-BA e região foi convocada a, de maneira solidária, assumir mais um grande desafio: agir de forma responsável e consciente. Julgou-se necessário ações específicas de conscientização com aproximação de informação sobre como proteger a si mesmos e suas famílias da Covid-19, priorizando o conhecimento científico. Com a expectativa de que as ações do projeto Checker News do IFBA campus Seabra-BA mobilizassem o corpo docente, técnico-administrativo e discente do campus, bem como a comunidade local, considerou-se que uma estratégia relevante e responsável seria o uso de redes sociais, o Instagram, sendo uma ferramenta de divulgação de informações sobre vários assuntos (PIZA, 2012). Justifica-se a adoção do Instagram pelo simples fato que, apesar de ser uma nova rede comparada ao Facebook, Twitter e Youtube, a plataforma alcançou a marca de 1 bilhão de usuários em setembro de 2018, mas não oferece sistema de denúncia de Fake News (TARDÁGUILA, 2019).

Para atingir o objetivo geral do projeto, foram analisadas várias notícias conectadas aos aspectos mais gerais (disseminação, prevenção e tratamento) do coronavírus. A seleção dessas mensagens foi de modo contínuo a partir do Facebook, Twitter e WhatsApp. As verificações se deram a partir da leitura de artigos científicos, em português e inglês, que contrastados com a notícia já veiculada na rede, atribuía-se o selo de verdade ou mentira e gerava-se novo conteúdo com uma linguagem clara e acessível para ser compartilhada no perfil do Instagram, atraindo a atenção dos seguidores.

Dentro do âmbito de pesquisa científica, por sua vez, têm-se, como objeto de pesquisa, os serviços de informação e as ações, promovidos pela equipe do projeto 
Checker News, para o enfrentamento das consequências e impactos gerados através da propagação de notícias falsas. Portanto, o objetivo principal deste artigo é analisar a relevância da divulgação científica como mecanismo para minorar as consequências deletérias da veiculação de notícias falsas sobre a Covid-19, através do compartilhamento de conteúdo científico e verificado no perfil do Instagram @fisica_contextualizada.

Os resultados revelam os benefícios da promoção da divulgação científica através do Instagram, uma vez que garante a acessibilidade e aumenta a visibilidade da ciência para além dos muros das instituições de ensino e centros de pesquisa. Verifica-se que há interesse por conteúdo produzido para esses fins, mas é preciso maiores incentivos para que a sociedade compreenda a importância da ciência através da educação científica. No meio acadêmico, este trabalho é relevante por evidenciar que o processo de divulgação científica, garantido através de registros a respeito dessas práticas, tem possibilidade de influenciar estudos futuros acerca deste objeto de estudo, que é relativamente novo, mas não tão explorado. As notícias sobre a Covid-19 devem ser avaliadas de forma crítica e para isso a sociedade deve ser devidamente instruída e, portanto, a divulgação científica é fundamental.

\section{REFERENCIAL TEÓRICO}

A crescente proliferação da Covid-19 deixou um sentimento de alerta na população, o temor espalhou-se. No entanto, é sabido que a humanidade ao longo de sua existência viveu outros momentos pandêmicos semelhantes e que, normalmente, matam mais que as guerras (SENHORAS, 2020). Para Chicrala (2020), "a diferença é que graças ao trabalho fantástico dos cientistas, cada vez conseguimos amenizar muito os seus efeitos".

As ciências básicas como química, física, biologia e matemática, bem como as ciências aplicadas em suas diversas áreas têm contribuído de forma definitiva para minimizar os impactos da doença. No entanto, a contribuição da ciência na pandemia de Covid-19 não fica evidente para uma pessoa não acadêmica. É difícil avaliar a importância da ciência, seja na busca de um medicamento ou uma vacina contra o coronavírus. A falta de uma visibilidade efetiva e diária dos feitos científicos resulta em desinformação. A população termina por ter acesso a todo tipo de notícia e, diante da pandemia, os danos podem ser enormes.

Nos últimos meses, vimos circular pelas redes sociais diversas notícias e informações duvidosas relacionadas à pandemia que estão cada vez mais direcionadas a um público específico, que não só acredita nas falsas informações, como também as compartilha por oferecerem respostas imediatas. Desse modo, essas notícias alcançam um número enorme de pessoas através do compartilhamento, criando uma situação de total descontrole que pode, inclusive, custar vidas. Entretanto, há uma maneira de contornar a situação que é a partir da educação científica, tornando as pessoas capazes de identificar uma notícia falsa e evitar o compartilhamento (BRANCO, 2020). Segundo Pilati (2018), é medida necessária para a sociedade globalizada estabelecer discussões que promovam o conhecimento científico contrapondo o que não passa de notícias falsas ou pseudociência.

$\mathrm{O}$ acesso a informações inadequadas tem influência social e na mudança de atitude frente a diversos assuntos (VOSOUGHI et al., 2018). Essa situação, em tempos de pandemia, deve ser tratada de forma a estimular a sociedade a pensar uma notícia criticamente com embasamento científico. É extremante necessário saber distinguir o que é verdadeiro (ou não) para realmente resultar em impactos positivos. Cabe, então, aos pesquisadores do país a missão de desenvolver estratégias de divulgação científica que atendam às necessidades da sociedade para torná-la apta à criticidade e propagadora de 
informações confiáveis tendo o cuidado de investigar se o que é proferido realmente procede (SILVA; MACEDO, 2018).

A pandemia reacende a necessidade de se alcançar uma verdadeira educação científica para contemplar pontos essenciais na construção de uma sociedade crítica e participativa dos movimentos sociais. Essa discussão reaparece, pois se ver a necessidade de que a sociedade avance na compreensão científica de mundo. Essa preocupação é claramente incluída na Base Nacional Comum Curricular (BRASIL, 2018, p.14):

No novo cenário mundial, reconhecer-se em seu contexto histórico e cultural, comunicar-se, ser criativo, analítico-crítico, participativo, aberto ao novo, colaborativo, resiliente, produtivo e responsável requer muito mais do que o acúmulo de informações. Requer o desenvolvimento de competências para aprender a aprender, saber lidar com a informação cada vez mais disponível, atuar com discernimento e responsabilidade nos contextos das culturas digitais, aplicar conhecimentos para resolver problemas, ter autonomia para tomar decisões, ser proativo para identificar os dados de uma situação e buscar soluções, conviver e aprender com as diferenças e as diversidades.

Nesse sentido, não há dúvidas de que as ciências humanas, exatas e sociais devem atuar de forma dinâmica, sendo imprescindíveis para o enfrentamento da pandemia de Covid-19. Nesse momento, pensar de forma integrada e entender que não é só uma questão biológica, mas também social é de fundamental importância nos desdobramentos das ações para combater o coronavírus (CHAPARRO, 2020). É preciso conduzir a sociedade a indagar, questionar, refletir, entender e ampliar a consciência. Com isso, estimular o pensamento crítico é passo principal para alcançar medidas preventivas e de combate às notícias falsas, bem como da Covid-19.

Saber administrar quantidades cada vez maiores de informação e ter discernimento para separar a 'Mentira' da 'Verdade' no enorme bazar de ideias digitais são habilidades imprescindíveis no mundo atual, e a educação, de modo geral, pode promover. No entanto, quais caminhos devemos seguir para perceber os disfarces da falsa ciência e os cuidados necessários? Como tornar a informação científica ao alcance de todos? O que o futuro nos reserva na luta contra o coronavírus? Não são questões simples de responder. Mas, entende-se que, uma vez que se trate dessas respectivas questões a partir dos avanços científicos, haverá maior significado para a sociedade, auxiliando na educação científica.

Desse modo, o principal interesse deste trabalho foi desenhar ações que poderão atenuar os efeitos das Fake News ao prestar um serviço de verificação de notícias. Essa ação tem apoio nas recomendações do Fundo das Nações Unidas para a Infância (UNICEF) que atua em parceria com a Organização Mundial da Saúde (OMS) e departamentos governamentais, defendendo a importância do uso de fontes seguras e oficiais de informação para combater Fake News em tempos de Covid-19 (UNICEF, 2020). Inclusive, o assunto Fake News preocupa até a Organização das Nações Unidas (ONU), como se nota na notícia de setembro de 2017:

Em meio ao aumento da proliferação de notícias falsas - 'fake news', em inglês - e do desafio de discernir entre informações verídicas e falsas, um fórum das Nações Unidas discutiu no início desse mês (7) formas de tratar deste complexo assunto. $\mathrm{O}$ encontro debateu caminhos para levar aos cidadãos as habilidades e ferramentas necessárias para avaliar a credibilidade de qualquer conteúdo da mídia ou de uma fonte de notícias" (MERELES, 2017).

É entendido que o processo de conscientização e enfrentamento exige domínio da temática e compreensão de seus efeitos mais danosos. Assim, não é suficiente saber o que é, como se propaga e/ou previne a Covid-19, é necessário agir. Os estragos da onda de Covid-19 são enormes e considerando a ocorrência de outras grandes epidemias ou pandemias ao longo da história têm-se duas certezas: 1) o mundo será um lugar diferente depois que a maré do coronavírus refluir e; 2) para vencer o coronavírus precisamos de 
uma sociedade mais informada e que evite a perpetuação das notícias falsas na internet (SOUSA JR. et al., 2020).

Para exercer o papel de informar a sociedade, adota-se o processo de divulgação científica através de rede social com foco no compartilhamento de imagens e vídeos. Entende-se que a divulgação científica está tipificada por um panorama bem diverso. Compreende-se, portanto, a divulgação científica como a "utilização de recursos, técnicas, processos e produtos (veículos ou canais) para a veiculação de informações científicas, tecnológicas ou associadas a inovações ao público leigo" (BUENO, 2010, p.2). Segundo Bueno (2010), o público leigo, em geral, não é alfabetizado cientificamente, o que compromete drasticamente o processo de compreensão das ciências ou dificulta o acompanhamento de determinados temas e assuntos, simplesmente porque eles não tiveram um acesso adequado a informações científicas. Ao divulgar a ciência para esse público, é preciso ser criativo e buscar uma linguagem acessível e atrativa.

Nessa perspectiva, este trabalho se propõe a refletir sobre a relevância da divulgação científica, aqui entendida como conteúdo direcionado a um público não acadêmico veiculado em rede social, o Instagram. É sabido que o Instagram já foi considerado rede social direcionado apenas para interação a partir de fotos e uso de efeitos, porém 10 anos após sua criação o aplicativo se expandiu para outros fins. $O$ uso dessa mídia foi ampliado para outras funções, sejam política, ou de movimentos de interesses coletivos, e também na educação. Com uma plataforma visual atraente e fácil de manusear, torna-se uma ferramenta interessante para a divulgação científica. A rede social passa a ser "responsável pelo compartilhamento de ideias, informações e interesses" (LORENZO, 2013, p. 20)

$\mathrm{Na}$ tentativa de acompanhar esse movimento no contexto educacional, alguns pesquisadores já fazem uso da rede social em questão para fins acadêmicos. Em Leão et al. (2020), questões relacionadas à saúde pública em redes sociais já inspiraram estudos semelhantes. Os autores citam pesquisas como: 1) estudo sobre a epidemia do vírus Ebola na África ocidental a partir da hashtag \#ebola (SELTZER et al., 2015); 2) estudo sobre a dengue, chikungunya, zika, aedes aegypti e microcefalia quanto a número de casos suspeitos, confirmados ou descartados pela Vigilância Epidemiológica do Estado de Santa Catarina, através do monitoramento de redes sociais como Facebook, Twitter, Instagram, Youtube e blogs (KLEIN et al., 2017); 3) estudo das palavras mais frequentes em referência à Covid-19, com análise de sentimentos relacionados, para identificar a opinião do público a respeito do tema (ZHAO et al., 2020). Nesse contexto, a aplicação do Instagram na educação torna-se útil ferramenta para potencializar o processo de ensino e aprendizagem ao experimentar a prática da divulgação científica com criatividade e engajamento promovendo estratégias didáticas para o acesso ao conhecimento científico.

Em sintonia com tais ideias, no presente artigo, uma vez estabelecido prestação de serviços de utilidade pública, concentram-se esforços em analisar como a produção de conteúdo relacionado à Covid-19 publicado na rede social Instagram, em um perfil específico, é percebida pela sociedade. Para isso, esta investigação toma como base teórica os estudos sobre redes sociais de Castells (2006) e Recuero (2009), além de desenvolver seu percurso metodológico composto por seleção e categorização dos dados, descrição e análise.

\section{METODOLOGIA}

A pesquisa de caráter descritivo pautou-se nas dimensões propostas por Novikoff (2010, p. 222) que "trata-se de uma abordagem teórico-metodológica, com todas as dimensões de preparação, estudo, desenvolvimento e apresentação de pesquisa 
acadêmico-científica" e foi dividida em três etapas para ser concretizada. A presente pesquisa teve como lócus a rede social Instagram. O recorte para amostra foi da primeira postagem relacionada ao projeto (18/06/20) até a última publicação selecionada (31/08/20), o que compreende um período de 10 semanas.

Na primeira etapa - estudo e análise das Fake News -, iniciada 01 de junho de 2020, foram analisadas várias notícias conectadas aos aspectos mais gerais (disseminação, prevenção e tratamento) do coronavírus. A seleção dessas mensagens foi de modo contínuo a partir do Facebook, Twitter e WhatsApp. Uma vez selecionada uma notícia, buscou-se correlacionar com a pesquisa científica verificando a lisura de informações que se encontra na internet.

Destacam-se que várias das notícias desmentidas através do projeto foram colhidas entre quatro grupos de 'notícias' da cidade de Seabra-BA. Aspecto que não foge ao sinalizado por Gragnani (2018), os grupos de família são o principal vetor de notícias falsas no WhatsApp. Segundo Fidalgo (2018), "talvez tenha explicações psicológicas para o fato das pessoas quererem contar uma novidade, especialmente sobre algo que já se entende previamente como correto, na bolha que se forma em sua proximidade, operando uma espécie de validação digital".

Na segunda etapa - divulgação científica sobre a Covid-19 e combate às Fake News - por meio de uma articulação virtual, a equipe envolvida no projeto produziu conteúdo com orientações simples sobre a veracidade (ou não) das notícias selecionadas com embasamento de artigos científicos, em português e inglês, ou páginas de instituições de pesquisa científica. Foram eleitos quatro selos para a divulgação, a saber: verdade, mentira, boa notícia e ação educativa - ilustrados na Figura 1.

Figura 1 - Conteúdo produzido pelo projeto Checker News

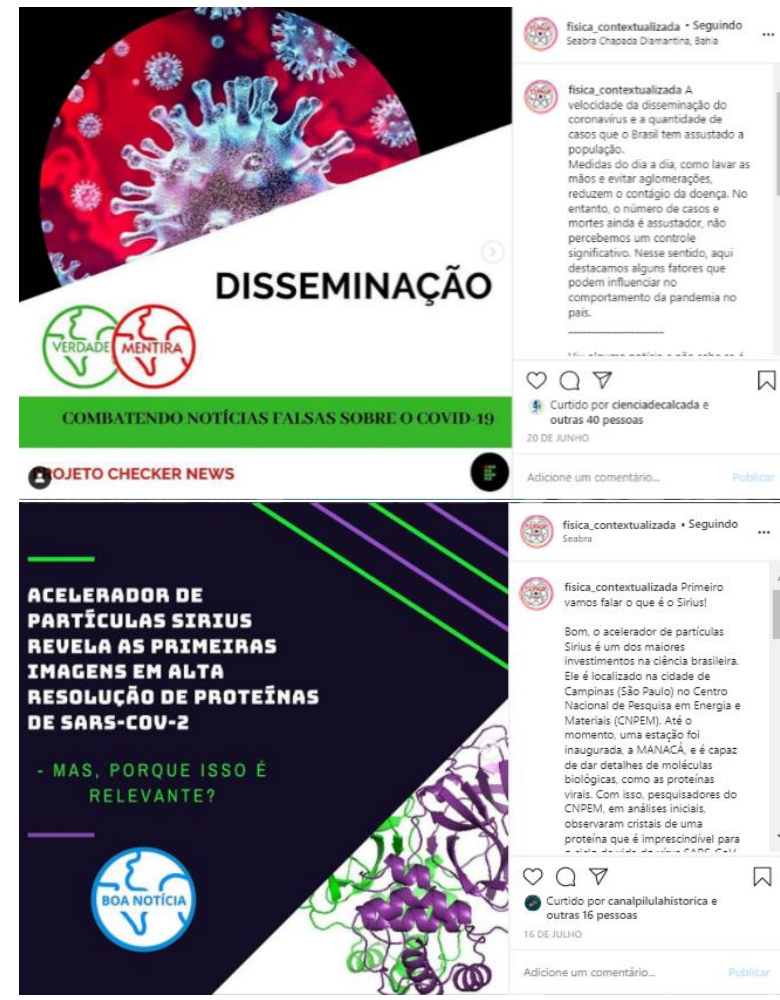

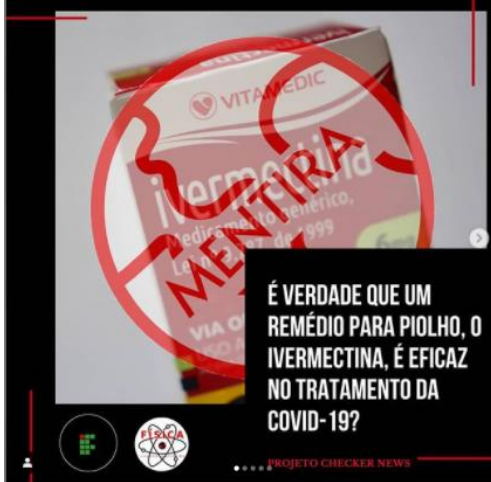

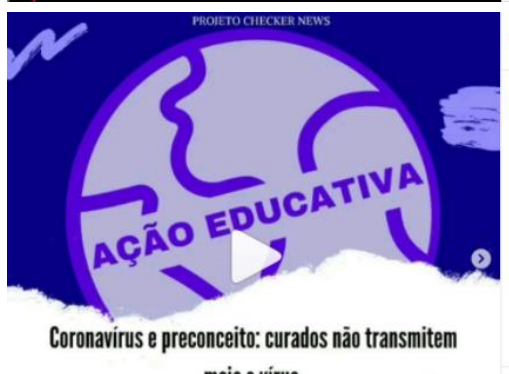
mais o virus.

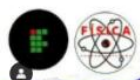

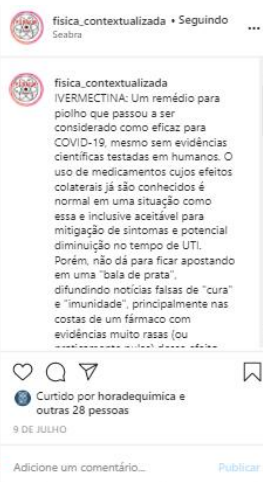

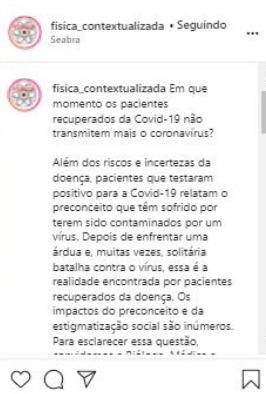

Fonte: capturada em https:/www.instagram.com/fisica contextualizada/ em Agosto de 2020.

Foi percebido que, entre as notícias falsas, havia aquelas que traziam esperanças e boas perspectivas às pessoas, assim os selos boa notícia e ação educativa tinham a intenção de incentivar a tomada de atitudes consciente e responsável, como por exemplo, não sentir vergonha por ter pego o vírus, esclarecimentos a respeito de medicamentos que 
podem ser prejudiciais, não julgar quem foi contaminado, entre outros. Já as notícias enganosas eram justificadas com o porquê de ser falsa e divulgou-se um conhecimento coerente, de modo didático e científico. Trabalhou-se para lidar com os efeitos imediatos dessas notícias e assim caminhar para frear a doença.

As mensagens foram veiculadas, a partir do dia 19 de junho, na rede através do Instagram no perfil @fisica_contextualizada. A escolha da rede social, um dos maiores aplicativos mundiais, deu-se por permitir o compartilhamento de vídeo e fotos, elementos utilizados na veiculação de informações. Em relação ao perfil em questão, sua escolha foi por já constar um número inicial de seguidores $(n=435)$, o que facilitaria a divulgação inicial do projeto.

Foram selecionadas, até 31 de agosto de 2020, 66 notícias devidamente agrupadas e totalizando 39 postagens distribuídas entre o Feed (33 posts) e o IGTV (6 vídeos). Essas postagens, acompanhadas de legendas, constituíram o meio de prestação de serviços de informação com conteúdo embasado em artigos científicos. Além disso, informações adicionais - como links de acesso aos artigos consultados - sobre as postagens podem ser consultadas no drive do perfil, o que reafirmava a confiabilidade das postagens.

Ainda, de forma inovadora com a finalidade primária de estimular o autocuidado promovendo informações seguras e efetivas, durante todo o período de efetivação do projeto, o Direct tornou-se espaço para receber mensagens de pessoas que questionavam a veracidade de alguma notícia. Essas eram apuradas e respondidas oficialmente se verdade ou mentira. Também, com auxílio do Software Microsoft Excel, foi disponibilizado um guia de checagem de informações. Com isso, a expectativa é de que as pessoas alcançadas consigam ter uma autopercepção da necessidade de promover no outro o mesmo pensamento: trabalhar com um objetivo comum para vencer a Covid-19.

A terceira etapa - tabulação de dados - foi realizada a partir do login no perfil. A compilação de dados contemplou as seguintes categorias: número de curtidas, número de itens que foram salvos, número de visitas do perfil, alcance, cidades, seguidores, faixa etária, gênero e data de postagem. A conta está cadastrada na categoria de Educação e, por isso, tem-se acesso a este tipo de dados. As notícias serão identificadas de P1 a P33 (Feed) e de V1 a V6 (IGTV).

\section{ANÁLISE E DISCUSSÃO DOS RESULTADOS}

As análises dos resultados obtidos vinculadas ao projeto Checker News seguem uma abordagem metodológica qualitativa. Primeiramente, apresentam-se, no Gráfico 1, os resultados observados através do Instagram, relacionados a aspectos gerais como descoberta, impressões, interações, visitas ao perfil, cliques no site, crescimento em seguidores das notícias veiculadas a rede social.

A categoria descoberta diz respeito ao alcance e às impressões que as publicações tiveram nos últimos 7 dias. Esses dados compreendem tanto os seguidores quanto as pessoas que descobriram os posts por acaso (na página explorar ou por hashtag e localização). De acordo com o Gráfico 1, é possível perceber que houve um alcance mediano de $<500$ para $>1500$.

Destaca-se, na penúltima semana de atuação, um crescimento exponencial. Nessa semana, foi veiculado o produto final, um Guia educativo de combate às Fake News em tempo de Covid-19 em formato de e-book, pensando em auxiliar no processo de combate às Fake News junto à comunidade, uma vez que notícias falsas continuam surgindo. $O$ objetivo é que as pessoas consigam ter autonomia na checagem de informações, colocando em prática o aprendizado promovido. Ainda sobre os aumentos perceptíveis no 
Gráfico 1, têm-se como justificativas plausíveis as divulgações sobre as ações do projeto

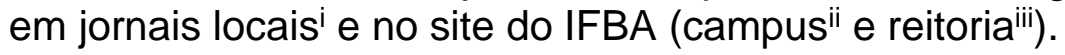

Gráfico 1 - Descoberta, Interações, Visitas ao perfil, Cliques no site, Crescimento em seguidores

$$
\begin{gathered}
\text { - Descoberta }- \text { interações }- \text { visitas ao perfil - Cliques no site } \\
\text { - Crescimento em seguidores }
\end{gathered}
$$

2000

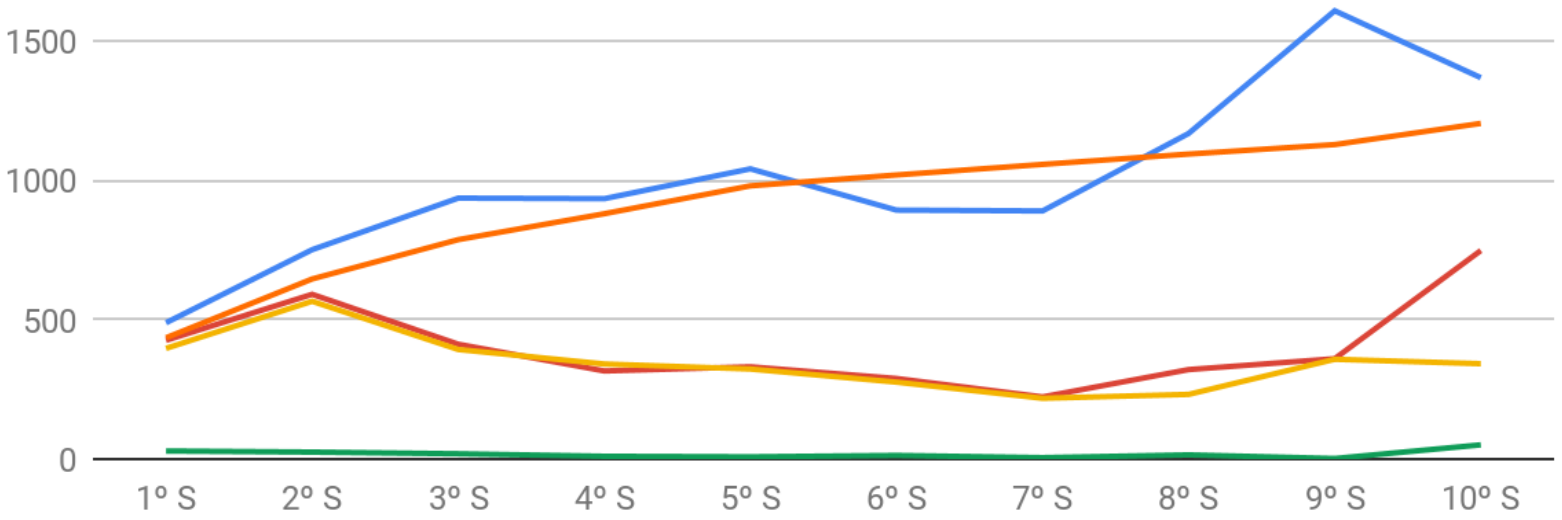

Fonte: @fisica_contextualizada, em agosto de 2020. Elaborado pelas autoras.

As interações são toda ação que um seguidor realiza na publicação (curtir, comentar, compartilhar), ou seja, o total de toques nas publicações ou perfil. Esses aspectos tiveram inicialmente um sutil aumento, mas seguiu em baixa. Já os cliques no site não foram alterados, mantendo-se em baixa por todo o período em análise. No entanto, na segunda semana de efetiva divulgação das ações do projeto, pôde-se observar um aumento exponencial no número de seguidores < 500 para $>1000$.

Alguns fatores podem influenciar a ascensão inicial e as respectivas oscilações durante o referido período. Ao fazer uma abordagem com foco nos interesses do público informação sobre a Covid-19 -, as postagens tendem a mexer com os anseios e expectativas através de recursos discursivos como textos e gráficos (BENETTI, 2013). Segundo Scalzo (2011), ao explorar novos ângulos do assunto, criam-se oportunidades de ir além da notícia e se sobressai com papel relevante o design e o aprofundamento do conteúdo.

Além disso, a periodicidade de publicações também pode influenciar nos resultados. Em se tratando de ambiente digital, como uma rede social, a frequência pode ter uma regularidade mais dinâmica. Neves e Coutinho (2016, p. 2) afirmam que "a tendência é que também haja um crescimento na reação dos seguidores, uma vez que o volume de informações e conteúdo se torna constante". No caso do projeto em questão, o formato de construção e propagação de conteúdo foi mantido durante o período supracitado, o que pode ter aproximado o leitor e o captado para o perfil, mas não o cativou para seguir interagindo efetivamente. Como pontua Recuero (2009), o capital social influencia a compreensão das relações sociais e suas conexões, assim como a produção de conteúdo.

Os seguidores são receptores coletivos de informação, que irão consumi-la e propagá-la por seus interesses e discursos, o que justifica a necessidade de manter uma constância de interação para aumento e permanência de interesse no perfil (CASTELLS, 2006). Na sequência, dados mais específicos são apresentados, como cidade de origem dos seguidores, faixa etária e gênero.

O Instagram só permite conhecer dados das 5 localizações com maior público. Como demonstrado no Gráfico 2, o maior número de seguidores provém do estado da 
Paraíba, das cidades de Campina Grande-PB e João Pessoa-PB, estado de origem da segunda autora.

Gráfico 2 - Localizações dos seguidores mais relevantes

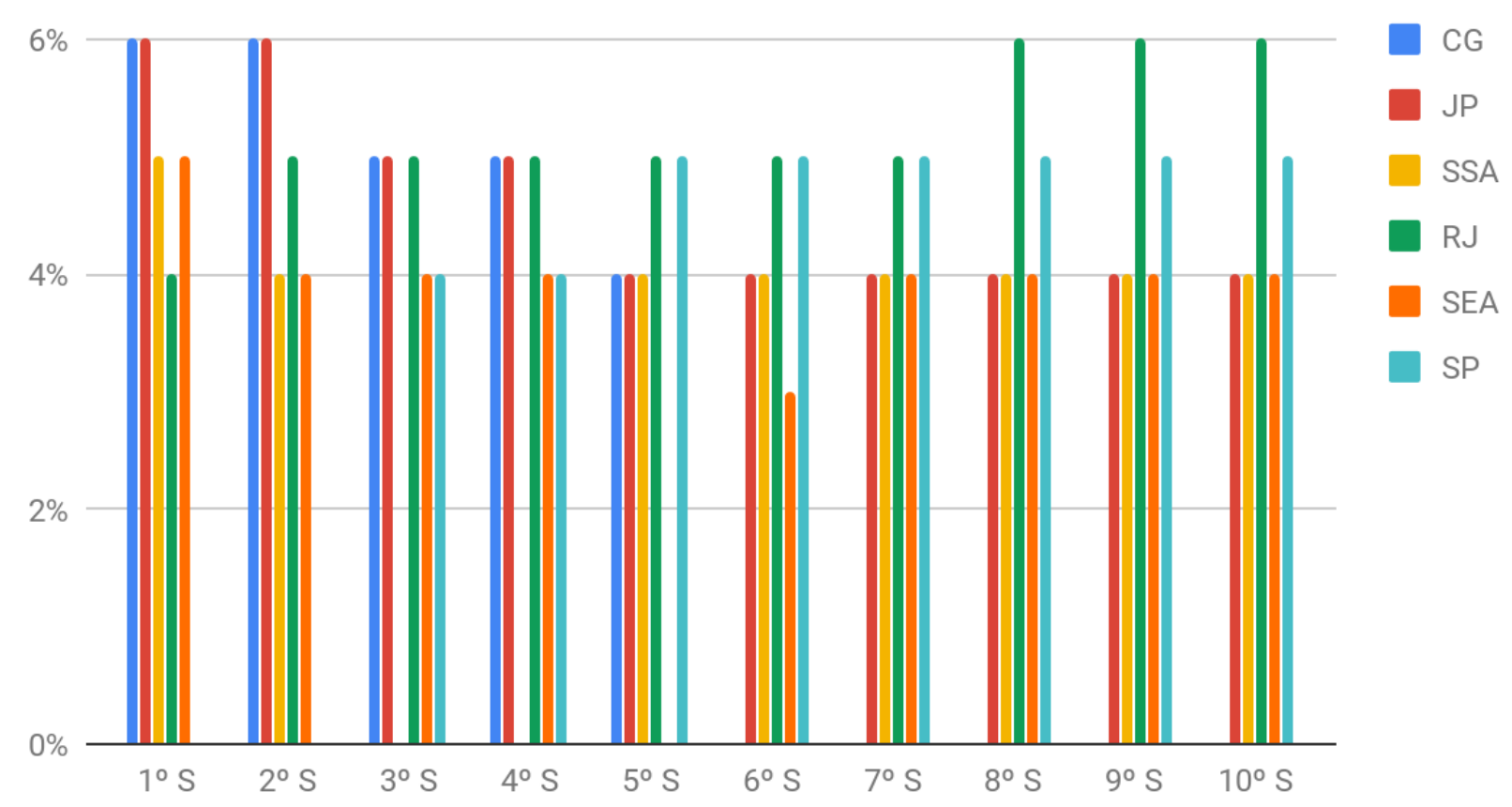

Fonte: @fisica_contextualizada, em agosto de 2020. Elaborado pelas autoras.

Outras cidades também foram sinalizadas, como São Paulo-SP, Rio de Janeiro-RJ, Seabra-BA e Salvador-BA.

A divulgação do perfil é feita apenas virtualmente, principalmente por perfis pessoais e pelo perfil da instituição de ensino a qual o projeto é vinculado.

O maior número de seguidores provenientes da Paraíba pode ser devido a maior divulgação no perfil pessoal da segunda autora.

No entanto, ver-se surgirem outras cidades, então o maior propósito, que é de divulgar informações confiáveis através dos posts à sociedade, é atingido, visto, também, o número crescente dos seguidores.

Em relação à Seabra-BA, cidade sede do vínculo do projeto, não se percebe um apoio em grande medida, o que pode ser justificado considerando fatores com as dificuldades no acesso à internet (principalmente em áreas mais remotas) e a ausência de projetos de divulgação científica desse tipo na região. Marca-se, portanto, a necessidade de maiores estímulos para esse tipo de trabalho.

No Gráfico 3, apresenta-se a faixa etária dos seguidores. A maior porcentagem de seguidores tem idades entre 25 e 34 anos (42\%) e idades entre 18 e 24 anos (28\%). Com esses dados, percebe-se que o perfil garantiu, em seu crescimento, um maior nível de engajamento e interações, com mais de $70 \%$ de usuários menores de 35 anos de idade.

Em relação à maior porcentagem do público jovem, sugere-se que esse público tem mais familiaridade com as novas tecnologias e usa os recursos de forma mais ativa.

A tecnologia está cada vez mais no cotidiano de toda sociedade e o jovem acaba tendo papel transformador, pois está aberto a novas experiências (MIRANDA, 2015).

É relevante notar que pessoas acima de 35 anos têm cada vez mais aderido as novas redes sociais e se faz necessário também maiores incentivos à inclusão digital. 


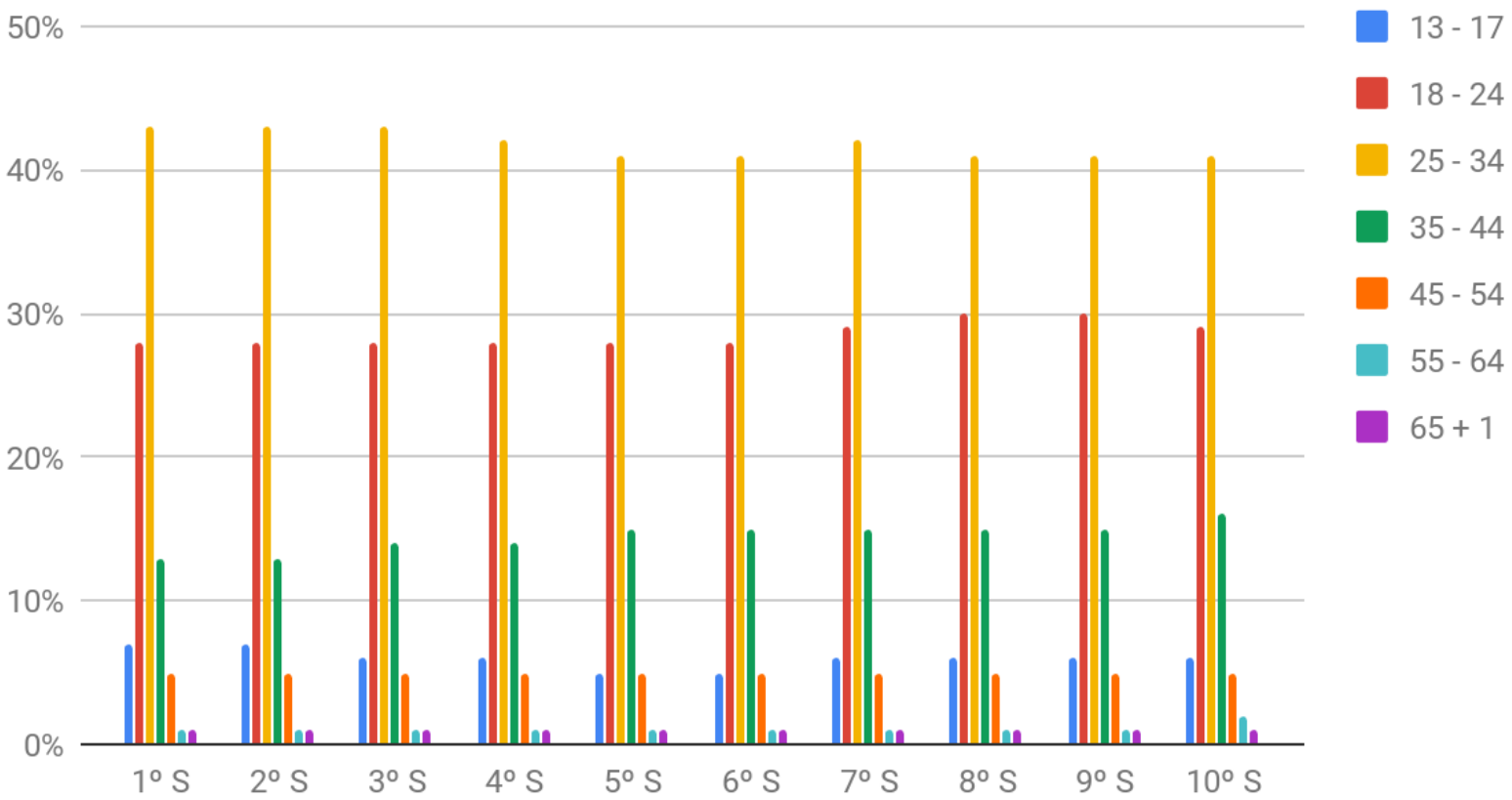

Fonte: @fisica_contextualizada, em agosto de 2020. Elaborado pelas autoras.

O Gráfico 4 demonstra a porcentagem em relação ao gênero dos seguidores. O perfil apresenta um equilíbrio em relação ao gênero, sendo, até quando verificado, feminino $(51 \%)$ e masculino (49\%). Essa proporção e sua evolução ao longo das semanas revelam que há um equilíbrio de interesse por conteúdo científico entre homens e mulheres e, no caso em questão, relacionado ao coronavírus. Uma das causas prováveis para esse equilíbrio de interesse na divulgação científica pode estar associada ao reconhecimento da importância de conhecer e saber lidar com assuntos tão urgentes e que envolvem as áreas de saúde, educação e bem-estar, que acabam fazendo parte dos seus interesses atuais.

Gráfico 4 - Gênero dos Seguidores

\section{mulher homem}

$60 \%$

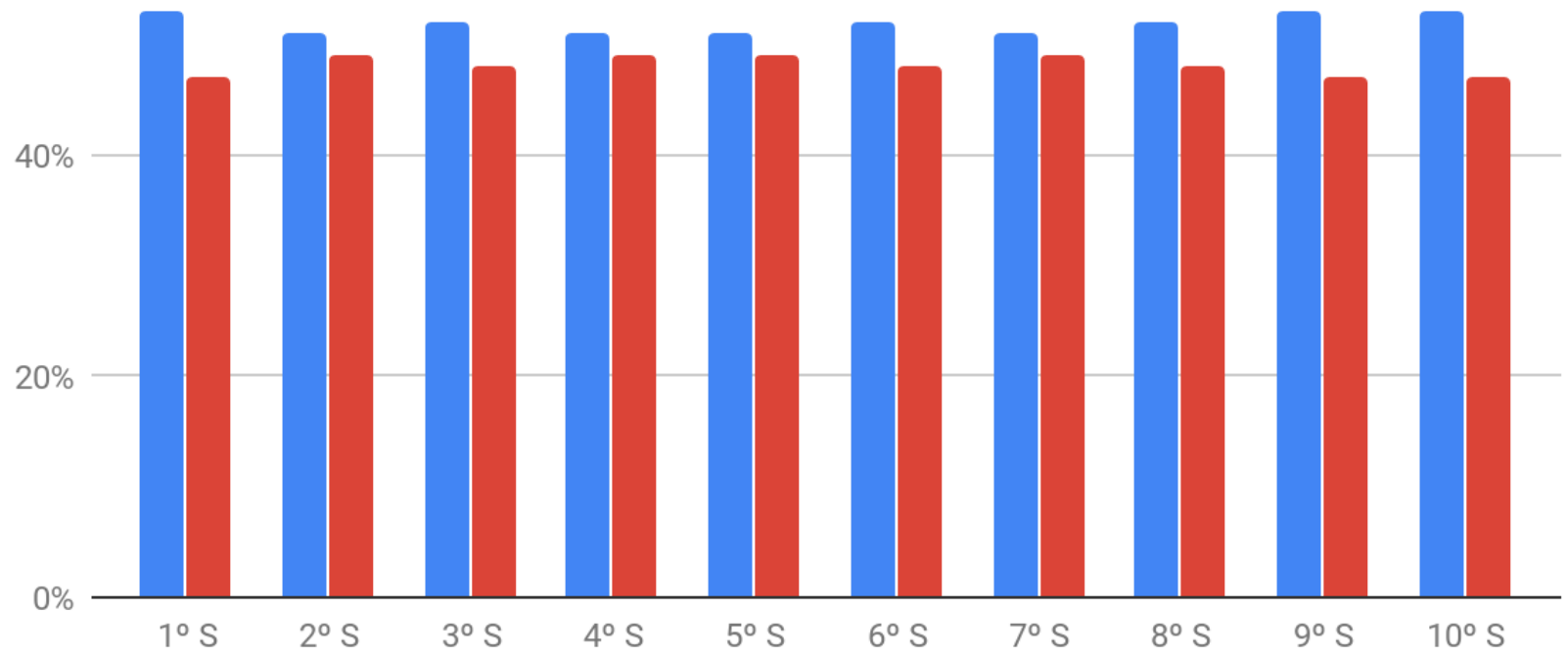

Fonte: @fisica_contextualizada, em agosto de 2020. Elaborado pelas autoras. 
Para a analisar as postagens e observar o progresso do perfil em relação a interações com os usuários, tabularam-se as datas das postagens, número de postagens, curtidas, salvos, compartilhamento e alcance (Tabela 1). Conforme Recuero (2014) apud Vasques (2019, p. 24),

o Instagram torna-se uma rede social a partir dessas interações, que são possíveis a partir de recursos disponíveis no aplicativo, como:

- Curtir: demonstrar ao ator da postagem o fato de ter apreciado a publicação. Além disso, também pode ser uma maneira de despertar a atenção do ator da postagem para a existência do seu usuário.

- Comentar: interação de diálogo junto à postagem do ator.

- Compartilhar: possibilidade de enviar ou repostar a postagem do ator para visualização de outros atores.

- Mensagem direta: possibilidade de conversar de maneira privada com outro usuário.

- Hashtag: a utilização de hashtag no texto da postagem cria a possibilidade de centralizar outras postagens de assuntos relacionados.

Junto a esses tipos de interações, soma-se a contabilização do Alcance que representa quantas contas únicas viram qualquer uma das publicações sem distinção entre "seguidor" e "usuário novo". Assim, observaremos os respectivos dados com a intenção de compreender como a divulgação de conteúdo durante um determinado período é percebida pelos seguidores, se há aumento de interesse ou se diminui com passar do tempo. $\mathrm{Na}$ Tabela 1, apresentam-se, ao longo das semanas de atuação, as 39 postagens distribuídas entre o Feed (P1 - P33 posts) e o IGTV (V1 - V6 vídeos), além de 1 Live evidenciando a respectiva interação do público alcançado.

Tabela 1 - Dados compilados do perfil @fisica_contextualizada (publicações)

\begin{tabular}{|c|c|c|c|c|c|c|}
\hline \multirow{2}{*}{$\begin{array}{l}\text { Semanas de atuação } \\
\text { 1S - 18/06 a 24/06 }\end{array}$} & \multicolumn{2}{|c|}{$\begin{array}{l}\text { Número de } \\
\text { postagens }\end{array}$} & \multirow{2}{*}{$\begin{array}{c}\text { Curtidas } \\
209\end{array}$} & \multirow{2}{*}{$\begin{array}{c}\text { Salvos } \\
9\end{array}$} & \multirow{2}{*}{$\begin{array}{c}\text { Compartilhamento } \\
62\end{array}$} & \multirow{2}{*}{$\begin{array}{c}\text { Alcance } \\
1.841\end{array}$} \\
\hline & $\begin{array}{c}\mathrm{P} 1-\mathrm{P} 4 \\
\mathrm{~V} 1-\mathrm{V} 2\end{array}$ & 6 & & & & \\
\hline 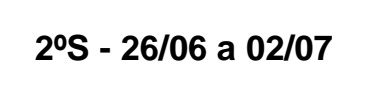 & $\begin{array}{l}\text { P5-P10 } \\
\text { Live }\end{array}$ & 7 & 140 & 4 & 22 & 1.624 \\
\hline $3^{\circ}=-03 / 07$ a $09 / 07$ & P11-P14 & 4 & 101 & 2 & 34 & 864 \\
\hline $4^{\circ} \mathrm{S}-10 / 07$ a $16 / 07$ & $\begin{array}{c}\text { P15-P18 } \\
\text { V3 }\end{array}$ & 5 & 87 & 2 & 3 & 897 \\
\hline 5S - 17/07 a $24 / 07$ & P19-P22 & 4 & 99 & 3 & 26 & 943 \\
\hline $6=5-25 / 07$ a $31 / 07$ & $\begin{array}{c}\text { P23-P25 } \\
\text { V4 }\end{array}$ & 4 & 90 & 5 & 24 & 820 \\
\hline $7^{\circ} \mathrm{S}$ - 01/08 a 08/08 & $\begin{array}{c}\text { P26-P27 } \\
\text { V5 }\end{array}$ & 3 & 52 & 3 & 16 & 590 \\
\hline $8=S-09 / 08$ a $15 / 08$ & P28-P29 & 2 & 47 & 2 & 14 & 481 \\
\hline 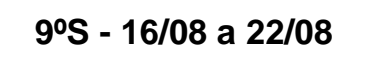 & P30-P31 & 2 & 87 & 9 & 25 & 634 \\
\hline 1095 - $23 / 08$ a $31 / 08$ & $\begin{array}{l}\text { P32-P33 } \\
\text { V5-V6 }\end{array}$ & 4 & 127 & 4 & 16 & 992 \\
\hline
\end{tabular}

Fonte: Dados da pesquisa (2020).

Ao examinarmos as categorias das postagens levantadas na Tabela 1, durante as dez semanas de atuação do projeto, podemos refletir acerca de alguns aspectos. Para isso, 
traçamos também o Gráfico 5, construído baseado nos quatro aspectos de interação em relação às postagens, de forma a sintetizar os resultados obtidos.

Gráfico 5 - Número de postagens, Curtidas, Salvos, Compartilhamento, Alcance

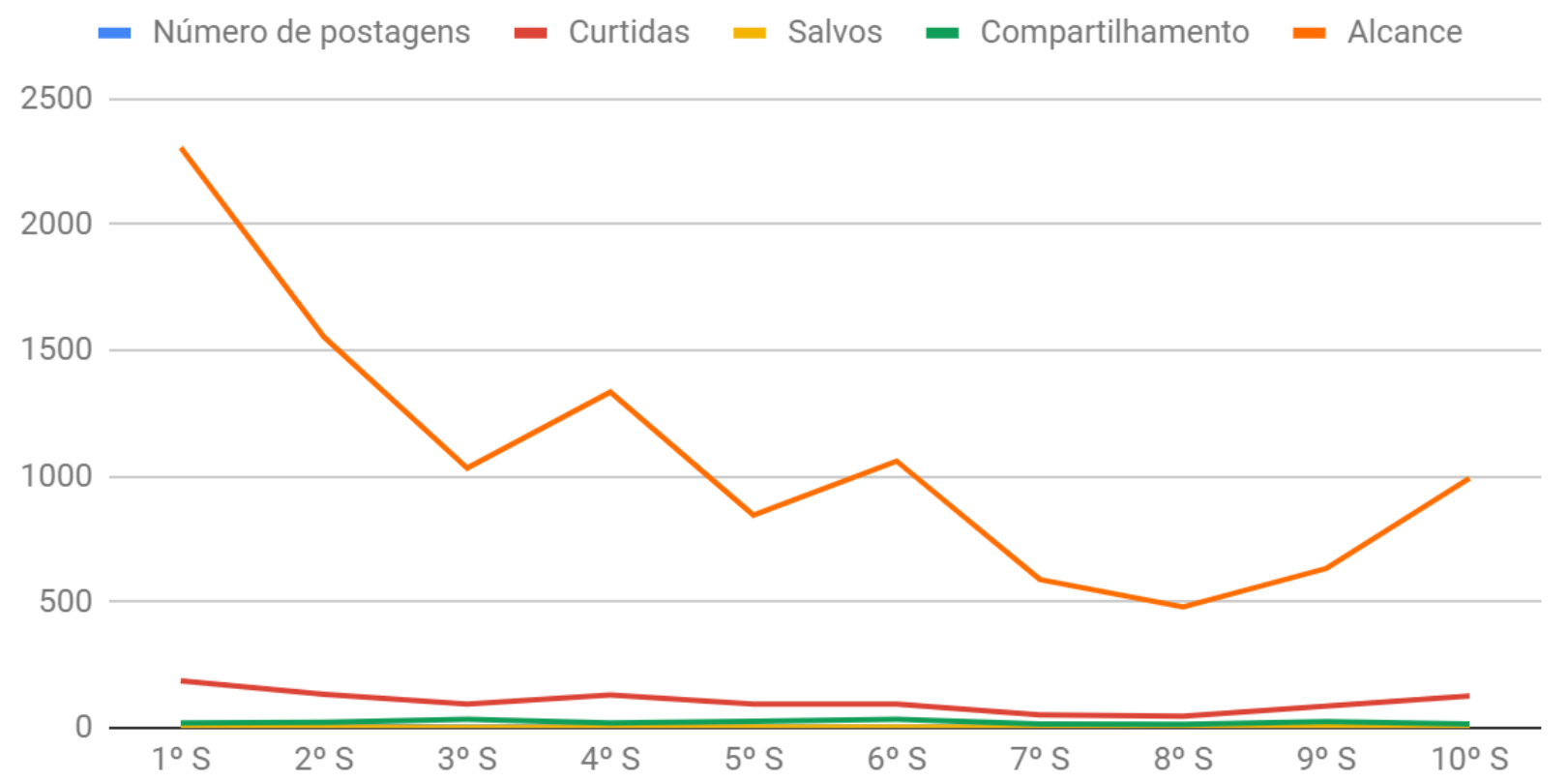

Fonte: @fisica_contextualizada, em agosto de 2020. Elaborado pelas autoras.

Ao examinar o Gráfico 5, percebem-se continuidades com uma diferença apenas no padrão do alcance. De maneira acentuada, a quantidade de pessoas alcançadas no início do projeto teve uma ordem decrescente com o passar das semanas. Esse dado específico significa que o conteúdo veiculado pelo projeto alcançou um bom número de pessoas, ainda que não seguissem o perfil. Sobre o conteúdo divulgado, têm-se alguns picos a serem observados nas Figuras a seguir.

Figura 2 - Vídeo postado no IGTV (V1)
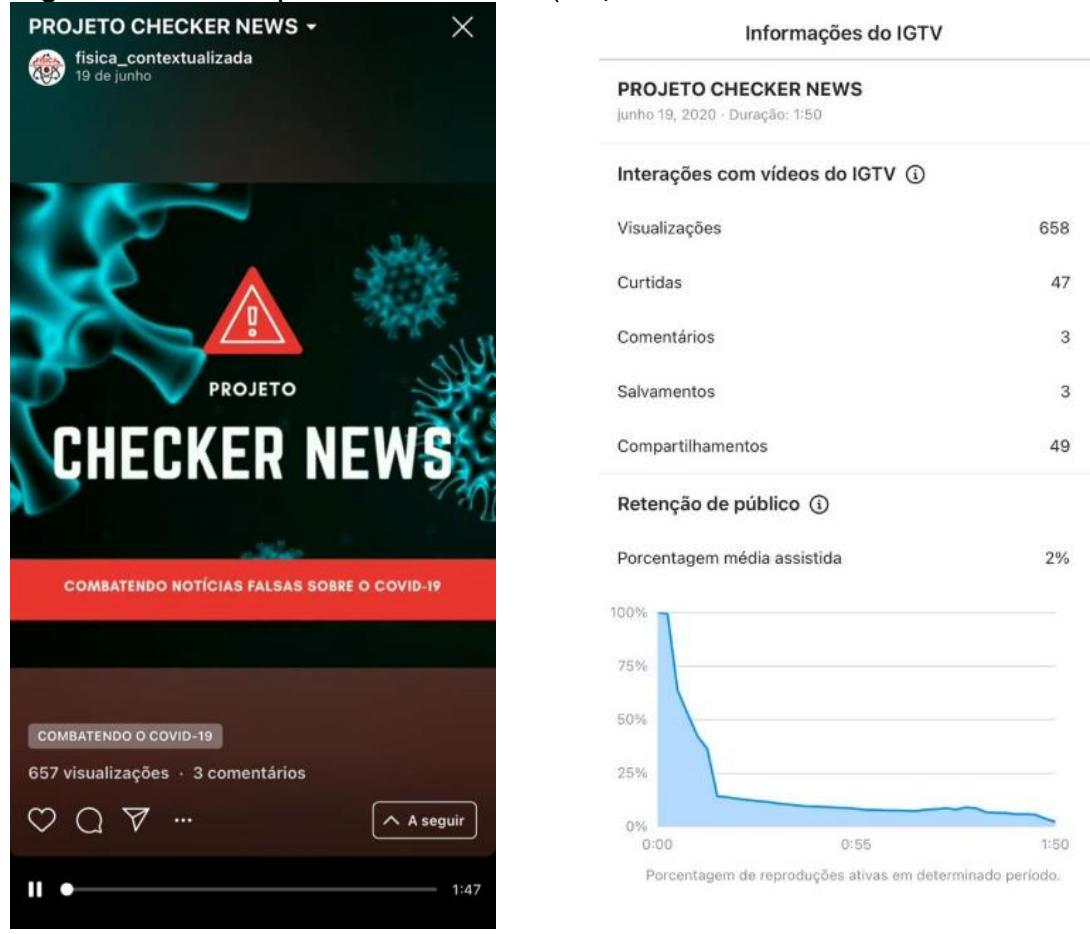

Fonte: capturadas em https://www.instagram.com/fisica contextualizada/ em agosto de 2020. 


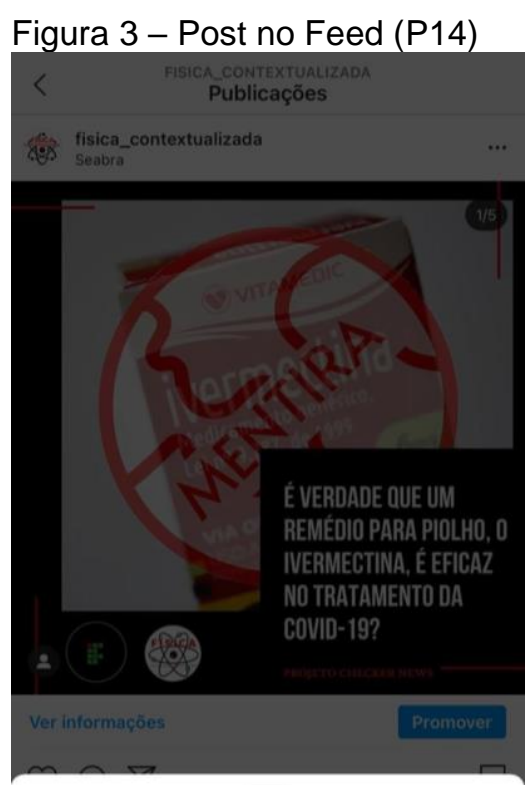

Informações da publicação

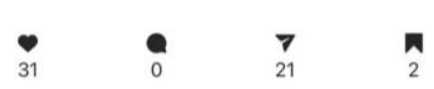

6

\section{6}

Figura 4 - Post no Feed (P31)

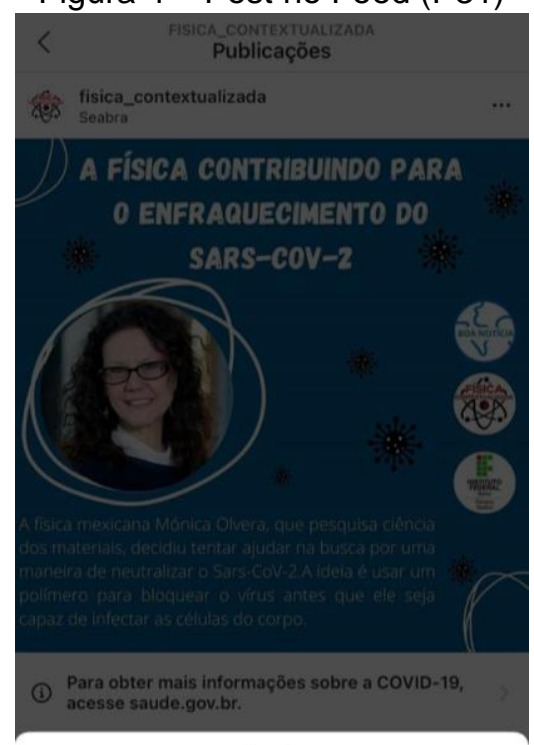

Informações da publicação

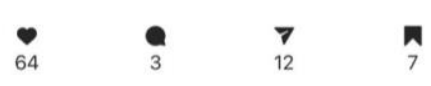

5

463

Fonte: capturadas em https://www.instagram.com/fisica contextualizada/ em agosto de 2020.

Na Figura 2, têm-se dados do vídeo de apresentação do projeto Checker News (V1). Através desse vídeo, foi apresentada a proposta de verificação de notícias, convidando a comunidade de Seabra-BA e região a conhecer mais sobre os aspectos relevantes para o combate da Covid-19. Os dados contabilizados de sua veiculação no Instagram foram de 658 visualizações e 49 compartilhamentos, o que torna esse vídeo o mais assistido e resulta que um alerta foi lançado quanto ao perigo das Fake News.

$\mathrm{Na}$ Figura 3, apresenta-se o post (P14) sobre a eficácia do Ivermectina com selo 'mentira'. Esse conteúdo, respaldado nos artigos de Mamakov e Mamakova (2020), Caly et al. (2020) e Pasternak (2020), rendeu o maior número de compartilhamento $(n=21)$. Com a ansiedade da população em obter um remédio eficaz para prevenir ou tratar a Covid-19, mesmo sem evidências científicas testadas em humanos, o uso de Ivermectina passou a ser considerado. Ao veicular esse conteúdo, contrário ao que vinha sendo compartilhado no WhatsApp e Facebook, muitas pessoas foram motivadas a evitar a automedicação. Inclusive, houve Feedback via Direct de dois seguidores que afirmaram comprar e, em um dos casos, chegou a usar o medicamento para prevenir a doença.

$\mathrm{Na}$ Figura 4, tem-se o post (P31) com selo 'boa notícia' sobre as contribuições da física para o enfraquecimento do Sars-Cov-2, marcou-se o maior alcance $(n=463)$. Nesse post, o conteúdo foi baseado em Qiao e Cruz (2020) e Contaifer (2020), dando destaque para a física aplicada a partir do trabalho de Mónica Olvera. Relata-se a possibilidade de bloquear o coronavírus, usando um polímero (espécie de molécula) e processos eletrostáticos entre a superfície do vírus e das células, antes que ele seja capaz de invadir e infectar as células do corpo humano. Possivelmente, o post foi bem visto e compartilhado por envolver uma ciência básica, a física, em um importante trabalho na corrida contra a Covid-19.

Ainda, embora tenham-se relatado até aqui exemplos de conteúdos produzidos e veiculados no perfil que foram bem vistos e aceitos pelo público, há também situações que chamam atenção. Os vídeos V2 (Figura 5) e V3 (Figura 6), postados no IGTV, tiveram números baixos de visualizações ( $n=68$ e $n=64$, respectivamente) e curtidas $(n=11$ e $n=9)$ 
se comparados, por exemplo, com o vídeo V6 (Figura 7) que teve 262 visualizações e 47 curtidas. Uma possibilidade para a baixa interação nos casos do V2 e V3 é o meio de produção. Nos casos dos vídeos V2 e V3, eles foram produzidos através do Powtoon - um site que permite a criação de apresentações na forma de slides e vídeos animados -, utilizando-se dos mesmos recursos de imagens. Possivelmente, o resultado visual não configurou conteúdo atraente ao público. Ao ser alterada a estrutura do vídeo, convidando um profissional de determinada área para expor sobre uma questão, a interação foi aumentada.

Figura 5 - Vídeo postado no IGTV (V2)

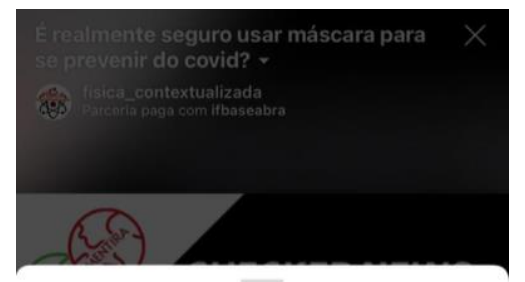

Informações do IGTV

É realmente seguro usar máscara para se prevenir c covid?

Interações com vídeos do IGTV (1)

Visualizaçōes

Visualizaç

Comentários

Salvamentos

Compartilhamentos
Figura 6 - Vídeo postado no IGTV (V3)

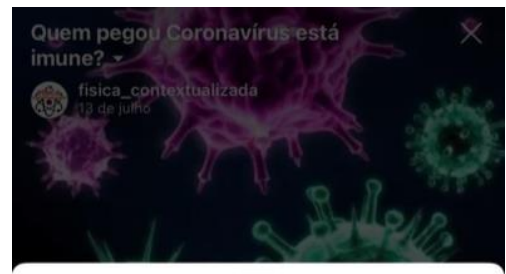

Informações do IGTV

Quem pegou Coronavírus está imune? jultho 13, 2020 - Duraçăo: 3:21

Interações com vídeos do IGTV (1)

Visualizaçōes

Curtidas

Comentários

Salvamentos

Compartilhamentos
Figura 7 - Vídeo postado no IGTV (V6)

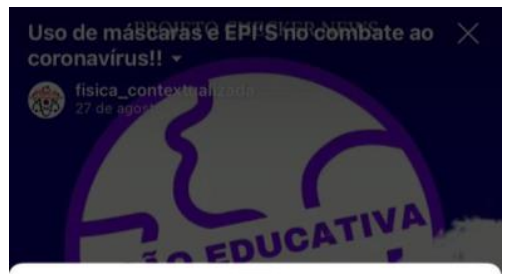

Informações do IGTV

Uso de máscaras e EPI'S no combate ao coronavíru: agosto 27, 2020 - Duraçấa: 7:01

Interações com vídeos do IGTV (1)

Visualizaçōes

262

Curtidas

Comentários

Salvamentos

Compartilhamentos

\section{7}

1

Fonte: capturadas em https://www.instagram.com/fisica contextualizada/ em agosto de 2020.

Portanto, manter um formato padrão em relação a design e edição para postagens no Feed parece não ser um obstáculo para interação. No entanto, no caso dos vídeos, foi possível perceber que a interação foi maior ao veicular vídeos explicativos com participações especiais. Os vídeos tinham menos de 5 minutos e tratavam sobre diferentes aspectos da Covid-19 com uma linguagem acessível ao público não especializado.

É importante destacar que o impacto das atividades on-line rendeu convite para participação em Live, em 29 de junho, transmitida no Instagram junto ao projeto 'Makers contra Covid-19', que também desenvolve ações para o combate à pandemia, ampliando o alcance inicial do projeto - momento único de reconhecimento das ações do projeto e de troca de ideias. É possível que essa Live tenha incentivado também o alcance de pessoas de outras regiões do país, como o caso do Rio de Janeiro e São Paulo.

Com um olhar mais minucioso, infere-se que a divulgação científica proposta no projeto Checker News estimulou diálogos entre a ciência e a sociedade ao envolver uma temática que repercute no campo da saúde, mídia, educação e cultura. O espaço no Instagram como canal informativo, e não apenas de entreter, com postagens diversas sobre a Covid-19, além da proposta de um serviço de verificação de notícias, revela-se como característica própria da produção do conhecimento científico e compreensão do que é, para que serve e a importância da ciência.

Diante de um tema de grande relevância, do qual pouco se sabia e pelo qual despertou grande interesse da sociedade, as demandas por informações e orientações tendem a ser intensas (MCCOMBS; VALENZUELA, 2007). Nesse cenário, veículos de comunicação tentam atender aos assuntos e necessidades do momento (CASTELLS, 
2006). Faz parte do seu escopo articular esses setores, de diversas formas, recorrendo a variadas estratégias e contando com diferentes plataformas.

Resta-se ainda uma pergunta, derivada de uma observação mais geral: por que as notícias falsas proliferam mais? Os resultados dessa pesquisa revelam que o interesse por notícias científicas oscila ao longo do tempo e depende do formato publicado. As notícias falsas, segundo pesquisa do Instituto de Tecnologia de Massachusetts (MIT), publicada na revista Science, edição de março de 2018, têm se difundido de maneira significativamente mais rápida, profunda e ampla do que os fatos verdadeiros. Segundo a pesquisa, "cada postagem verdadeira atinge, em média, mil pessoas, enquanto as postagens falsas mais populares - aquelas que estão entre o $1 \%$ mais replicado - atingem de mil a 100 mil pessoas" (dados que se confirmam a partir da atuação do projeto em questão).

Tem-se, portanto, que a desinformação na sociedade da informação é tão preocupante quanto o coronavírus. Ao ponto que, logo após o projeto desmentir uma notícia falsa que afirmava 'o uso da máscara de proteção prejudica as trocas gasosas e torna 0 sangue mais ácido', outra fake foi compartilhada no mesmo dia. Essa afirmava que 'a Itália encontrou a cura da Covid-19'. Essas mensagens são virais, muito mais que a promoção do conhecimento científico, o que torna o trabalho maçante e desafiador.

Conclui-se que a responsabilidade pela propagação das notícias falsas é da sociedade, pois a procura de novidades (mesmo que inventadas) atrai a nossa atenção e contribui para a tomada de decisão, encorajando-nos a compartilhar. A novidade dá a sensação de que atualizamos o nosso entendimento sobre o mundo. Assim, é preciso aproximar da sociedade uma noção geral sobre determinados conceitos e temas da ciência, uma noção sobre a natureza da atividade científica e uma consciência do papel da ciência a fim de contribuir na tomar decisões e a compreender fatores relativos às consequências do avanço científico (OLIVEIRA, 2013). Em momentos como este, de crise e tensão - mas também de fortalecimento de laços -, a sociedade também é chamada a agir. A divulgação científica que já era importante para levar a ciência para além das instituições de pesquisa e das revistas acadêmicas, com a pandemia ela se tornou ainda mais essencial para elencar os estudos relevantes e combater a desinformação. Desde o início da pandemia, vemos uma mobilização crescente no campo, com um número cada vez maior de instituições e divulgadores aderindo à causa. Essas ações precisam ser cada vez mais incentivadas na sociedade moderna.

\section{CONSIDERAÇÕES FINAIS}

Ainda é cedo para tirar conclusões sobre os efeitos da pandemia de Covid-19. As reflexões mais sensatas, completas e duradouras serão feitas, necessariamente, a posteriori. Mas é inevitável não refletir sobre o que está acontecendo agora, especialmente quando se trabalha diariamente no campo da divulgação científica, tanto na prática quanto na teoria - como é o nosso através do referido projeto.

Como discutido, o progresso científico e tecnológico vivenciado nos dias hodiernos e a dinamização da informação e conhecimento mediante as redes sociais acabaram por influenciar diretamente na educação científica, uma vez que a sociedade se interessa por conteúdos científicos. Nesse contexto, as mídias sociais, decerto, representaram um marco importante na modificação de visão de mundo, posto que possibilitaram 0 compartilhamento, a divulgação, a comunicação e o acesso a informações confiáveis, em um período tão necessário, de forma mais dinâmica, agregando a elas valor. Da apreciação dos dados levantados, revela-se impacto inicial de interesse em compreender o que são as chamadas Fake News com atenção a questões relacionadas com a Covid-19. 
A incessante busca por informações e soluções rápidas abre espaço para a proliferação das Fake News, disseminadas como um vírus tão danoso quanto o Sars-CoV2. Percebe-se ser essencial a continuidade do trabalho, desmentindo publicações falsas e promovendo o acesso facilitado ao conhecimento científico. Ainda, o contato constante com as notícias veiculadas promove um alerta para se enxergar a internet de uma forma diferente. A internet é ótima ferramenta de divulgação de conteúdo, porém esse conteúdo pode ser enganoso, manipulado e compartilhado milhares de vezes. Mas, pode ser usada para desmentir, apresentar fatos e, principalmente, compartilhar notícias verdadeiras, democratizando a ciência, e isso o projeto fez.

Como resultado principal, tem-se o incentivo à produção de conteúdo, dialogando com os argumentos científicos, em específico, sobre as falsas promessas de tratamento da Covid-19, de modo a construir argumentações com um embasamento crítico e reflexivo sobre o que está sendo divulgado e aplicado. O momento é de aglutinar as forças democráticas não somente para derrotar a Covid-19, mas de se preparar para enfrentá-la e para garantir a vida e o bem-estar da sociedade. Portanto, a função cumprida neste estudo foi a promoção do conhecimento amplo da ciência que pode promover o sentimento de esperança e de métodos seguros para tratar e conter o vírus. Levou-se informação à comunidade, possibilitando prevenção e combate à disseminação do coronavírus, bem como ações que podem atenuar seus efeitos. Neste momento, cada vida importa. Cada contaminação evitada é relevante para conter a disseminação da doença.

De fato, somente o conhecimento empregado e focado no problema pode contribuir para a solução. Decretos governamentais minimizam o problema, mas não o resolvem. Estamos vivendo uma pandemia, que para muitos de nós é novidade. No entanto, os indicativos são de que teremos diversos problemas parecidos no futuro próximo. A lição tem que ser aprendida agora. Temos que nos preparar com antecedência e permitir que informações científicas, de forma clara e precisa, cheguem à massa da população. É preciso estabelecer uma ponte de acesso ao conhecimento que vem sendo produzido, pois estar bem informado é essencial para a proteção coletiva.

Por fim, a prática da divulgação científica, por meio da internet, nesse período de pandemia, tornou-se oportunidade ímpar de não apenas mostrar sua importância e qualidade, mas para promover uma reaproximação necessária entre a ciência e a sociedade, no seu sentido mais amplo. É hora de revalorizar a ciência e sobretudo de resgatar a sua legitimidade perante a sociedade. Nesse sentido, a visibilidade inicial do projeto Checker News é um exemplo porque mostra que há muito a comunicar e que a sociedade tem interesse em saber.

Fica o aprendizado das potencialidades ao estabelecer uma linguagem acessível à sociedade através das redes sociais, com conteúdos específicos, para gerar engajamento e compreensão de um determinado tema. E, que, para promover o pensamento crítico e participativo, resta-se, ainda, superar os desafios de uma ciência para cientistas. Precisamos que as pessoas entendam a ciência por meio de uma maneira atrativa, adequada aos seus contextos e inteligível ao público leigo.

\section{REFERÊNCIAS}

ALLCOTT, H.; GENTZKOW, M. Social Media and Fake News in the 2016 Election. Journal of Economic Perspectives, Pitsburgh, American Economic Association, v. 31, n. 2, p. 211-236, 2017. 
BENETTI, M. Revista e jornalismo: conceitos e particularidades. In: TAVARES, Frederico de Mello B.; SCHWAAB, Reges (Orgs.). A revista e seu jornalismo: Porto Alegre: Penso, 2013.

BRAGA, R. M. C. A Indústria das Fake News e o Discurso de Ódio. In: PEREIRA, R. V. (org.) Direitos Políticos, Liberdade de Expressão e Discurso de Ódio. Belo Horizonte: IDDE, 2018. p. 203-220.

BRANCO, S. Fake News e os Caminhos para Fora da Bolha: Efeitos do feed de notícias do Facebook e a necessidade de alfabetização digital. Instituto de Tecnologia Social, 2017.

BRASIL. Base Nacional Comum Curricular (BNCC). Educação é a Base. Brasília, MEC/CONSED/UNDIME, 2018.

BUENO, W. C. Comunicação científica e divulgação científica: aproximações e rupturas conceituais. Inf. Inf., Londrina, v. 15, n. esp, p. 1 - 12, 2010.

CALY, L.; DRUCE, D. J.; CATTON, G. M.; JANS, D. A.; WAGSTAFF, K. M. The FDAapproved drug ivermectin inhibits the replication of SARS-CoV-2 in vitro. Biotechnology \& Biotechnological Equipment. Antiviral Research. v. 178, June 2020.

CASTELLS, M. A Sociedade em Rede: do Conhecimento à Política. In: CASTELLS, Manuel; CARDOSO, Gustavo (Orgs.). A Sociedade em Rede: Do Conhecimento à Acção Política. __. Imprensa Nacional -Casa da Moeda, 2006, p. 17-30.

CHAPARRO, L. A medicina não é suficiente: por que precisamos das ciências sociais para acabar com essa pandemia. Tradução de Bruno Leal. In: Café História - História feita com clique. Disponível em: https://www.cafehistoria.com.br/ciencias-sociais-novocoronavirus-pandemia/. ISSN: 2674-5917. Acesso em: 20 abr. 2020.

CHICRALA, K. A física por trás das soluções ao novo coronavírus. São Carlos agora, 2020. Disponível em: https://www.saocarlosagora.com.br/coluna-sca/scarlos-no-mundoda-ciencia-e-da-tecnologia/124867. Acesso em: 08 set. 2020.

CONTAIFER, J. Cientista encontra "ponto fraco" que pode inativar o coronavírus. Metrópoles, 2020. Disponível em: https://www.metropoles.com/saude/cientista-encontraponto-fraco-que-pode-inativar-o-coronavirus Acesso em: 15 out. 2020.

FIDALGO, A. A. Fake News e a Cidadania Digital. 2018. Disponível em: https://www.tiespecialistas.com.br/?s=Fake+NEWS. Acesso em: 10 set. 2020.

GAROFALO, G. Covid-19 - Doença do novo coronavírus. Unicef, 2020. Disponível em: $<$ <ttps://www.unicef.org/brazil/coronavirus-covid-19>. Acesso em: 08 set. 2020.

GRAGNANI, J. Pesquisa inédita identifica grupos de família como principal vetor de notícias falsas no WhatsApp. BBC. 2018. Disponível em:

https://www.bbc.com/portuguese/brasil-43797257. Acesso em: 28 abr. 2020. 
KLEIN, G. H.; GUIDI NETO, P.; TEZZA, R. Big Data e mídias sociais: monitoramento das redes como ferramenta de gestão. Saúde e Soc., São Paulo, v. 26, n. 1, p. 208-217, Mar. 2017.

LEÃO, C. F.; SERAFIM, L. S.; NUNES, D. M.; PEREIRA, G. C. Covid-19 em revistas no Instagram: uma análise de conteúdo relacionada às orientações do UNICEF e da OMS. Paradoxos, Uberlândia, v. 5, n. 1, p. 20-35, jan./jun. 2020.

LORENZO, E. M. A Utilização das Redes Sociais na Educação: A Importância das Redes Sociais na Educação. 3 ed. São Paulo: Clube de Autores, 2013.126p.

LUPA. Lupa fecha parceria com Facebook e vai checar posts feitos na plataforma. Piauí/Folha de S. Paulo, Rio de Janeiro, 10 de mai. de 2018. Disponível em: https://piaui.folha.uol.com.br/lupa/2018/05/10/verificacao-de-noticias-lupa-facebook/ Acesso em: 15 out. 2020.

MATSUKI, E. boatos.org/, 2013. Disponível em: https://www.boatos.org/. Acesso em: 15 out. 2020.

MCCOMBS, M.; VALENZUELA, S. The Agenda-Setting Theory. Cuadernos de Información. n. 20, 2007, p. 44-50. ISSN: 0716-162x. Disponível em: file:///C:/Users/USUARIO/Dropbox/My\%20PC\%20(DESKTOP0T39A9F)/Downloads/The_Agenda_Setting_Theory.pdf Acesso em: 15 out. 2020.

MERELES, C. Notícias falsas e pós-verdade: o mundo das fake news e da (des)informação. 2017. Disponível em: http://www.politize.com.br/noticias-falsas-posverdade Acesso em: 28 abr. 2020.

MIRANDA, G. V. Jovens e tecnologia: a consolidação de uma nova geração para a mudança dos meios tradicionais. Comunicação \& Mercado, v. 04, n. 10, 2015. p. 43-55.

MOMAKOV, G.; MOMAKOVA, D. Ivermectin as a potential COVID-19 treatment from the pharmacokinetic point of view: antiviral levels are not likely attainable with known dosing regimens. MedRxiv, May 22, 2020.

NEVES, M. C. P.; COUTINHO, R. E. T. O Instagram como ferramenta de divulgação de conteúdo: Análise das postagens da Espanha na fase de grupos da EURO 2016. In: CONGRESSO BRASILEIRO DE CIÊNCIAS DA COMUNICAÇÃO, 39., São Paulo, Anais..., São Paulo, 2016. NOVIKOFF, C. (orgs.). Dimensões Novikoff: um constructo para o ensino um constructo para o ensino-aprendizado da pesquisa. In: ROCHA, J.G. Desafios da práxis educacional à promoção humana na contemporaneidade. Rio de Janeiro: Espalhafato Comunicação, p. 211- 242, 2010.

OLIVEIRA, C. I. C. A educação científica como elemento de desenvolvimento humano: uma perspectiva de construção discursiva. Revista Ensaio: Belo Horizonte, v.15, n. 02, p. 105-122, 2013. DOI: https://doi.org/10.1590/1983-21172013150207 
PASTERNAK, N. Ivermectina é o novo bezerro de ouro da pandemia. Revista Questão de Ciência, 2020.

PILATI, R. Ciência e pseudociência: por que acreditamos naquilo em que queremos acreditar. São Paulo: Editora Contexto, 2018.

PIZA, M. V. O fenômeno Instagram: considerações sob a perspectiva tecnológica. Brasília: 2012.

QIAO, B. e CRUZ, M. O. Enhanced Binding of SARS-CoV-2 Spike Protein to Receptor by Distal Polybasic Cleavage Sites. ACS Nano 2020, v. 14, n. 8, p. 10616-10623. 2020.

QUAN-XIN LONG et al., Clinical and immunological assessment of asymptomatic SARSCoV-2 infections. Nature Medicine, v. 26, p. 1200-1204. 2020.

RECUERO, R. C. Redes Sociais na Internet. Porto Alegre: 2ª Ed. Sulina, 2009.

RECUERO, R. C. A conversação em rede: comunicação mediada pelo computador e redes sociais na internet. Porto Alegre: Sulina, 2014. (Coleção Cibercultura).

ROBBIANI, F. D.; GAEBLER, M.; NUSSENZWEIG, M. C. Convergent antibody responses to SARS-CoV-2 in convalescent individuals. Nature. v. 584, p. 437-442. 2020.

SCALZO, M. Jornalismo de revista. São Paulo: Contexto, 2011.

SELTZER, E.K. et al. The content of social media's shared images about Ebola: a retrospective study. Public Health (129.9). p. 1273-1277, setembro, 2015. Reino Unido. DOI: https://doi.org/10.1016/i.puhe.2015.07.025

SENHORAS, E. M. Coronavírus e o papel das pandemias na história humana. Revista Boca. ano II, v. 1, n. 1, Boa Vista, 2020.

SILVA, A. J. D.; MACEDO, I. M F. Fake News: Leitura em múltiplas fontes de formação continuada. In: Anais do XVI CONGRESSO INTERNACIONAL DE TECNOLOGIA NA EDUCAÇÃO, 16., 2018, Pernambuco. Anais... Olinda: SENAC-PE, 2018.

SOUSA JÚNIOR, J. H.; RAASCH, M. SOARES, J. C.; RIBEIRO, L. V. H. A. S. Da Desinformação ao Caos: uma análise das Fake News frente à pandemia do Coronavírus (COVID-19) no Brasil. Cadernos de Prospecção - Salvador, v. 13, n. 2, Edição Especial, p. 331-346, abril, 2020.

TARDÁGUILA, C. Instagram tem 1 bilhão de usuários, mas não oferece sistema de denúncia de fake News. Época - Globo.com, 2019. Disponível em:

https://epoca.globo.com/instagram-tem-1-bilhao-de-usuarios-mas-nao-oferece-sistemade-denuncia-de-fake-news-

23370668\#: :text=Instagram\%20tem\%201\%20bilh\%C3\%A30\%20de,den\%C3\%BAncia\%2 0de\%20fake\%20news\%20\%2D\%20\%C3\%89poca Acesso em: 21 jun. 2020. 
UNICEF. Coronavirus disease (COVID-19): What parents should know. UNICEF. 2020. Disponível em: https://www.unicef.org/stories/novel-coronavirus-outbreak-what-parentsshould-know Acesso em: 21 jun. 2020.

VASQUES, D. O uso do Instagram como ferramenta de reposicionamento de marca: uma análise do wok side bar. Universidade Federaldo Rio Grande do Sul. Faculdade de Biblioteconomia e Comunicação, 2019.

VOSOUGHI, S.; ROY, D.; ARAL, S. The spread of true and false news online. Social Science, v. 359, n. 6380, p. 1146-1151, 2018.

ZHAO Y.; CHENG S.; YU X.; XU H. Chinese Public's Attention to the COVID-19 Epidemic on Social Media: Observational Descriptive Study. J Med Internet. Res 2020. 4 de maio; 22(5):e18825. DOI: 10.2196/18825

\footnotetext{
'Matérias e programas de divulgação das ações do projeto

I. \#Chapada: Projeto de extensão do Ifba de Seabra visa combater a desinformação e 'fake news' em tempos de pandemia. Disponível em https://jornaldachapada.com.br/2020/08/31/chapada-projeto-de-extensao-doifba-de-seabra-visa-combater-a-desinformacao-e-fake-news-em-tempos-de-pandemia/

II. Chapada News - O Portal de Notícias da Chapada Diamantina. Disponível em https://www.chapadanews.com/projeto-de-extensao-do-ifba-campus-seabra-lanca-guia-educativo-decombate-as-fake-news/

III. TV UNEB - Seabra (1,5 mil inscritos): Episódio 17 - Boletim da Semana Conheça o projeto de extensão Checker News: @fisica_contextualizada, no Instagram https://www.youtube.com/watch?v=BGdZK2y4wBc

IV. PAPO COVID NA CHAPADA: Enfrentando a Pandemia: as ações das instituições educacionais da Chapada Apresentação do projeto. Disponível em https://www.youtube.com/watch?v=41ZvUNuoeMw\&t=4172s

ii Projeto de extensão do IFBA Câmpus Seabra lança guia educativo de combate às Fake News. Disponível em https://portal.ifba.edu.br/seabra/noticias/noticias-seabra/projeto-de-extensao-do-ifba-campus-seabra-lanca-guiaeducativo-de-combate-as-fake-news

iii Projeto do IFBA de combate às fake news repercute em eventos científicos do Nordeste e nacionais. Disponível em https://portal.ifba.edu.br/noticias/2020/projeto-do-ifba-de-combate-as-fake-news-repercute-em-eventos-cientificosdo-nordeste-e-nacionais
} 